\title{
In vitro Assessment of the Antioxidant Effect of Cunila microcephala Benth Infusion (Poejo) on Erythrocytes from Individuals with HIV/AIDS
}

\author{
Roberta Cattaneo Horn ${ }^{1,2}$, Natacha Cossettin Mori ${ }^{1}$, Juliana Sorraila de Oliveira ${ }^{1}$, Paulo Ricardo Moreira ${ }^{1}$, \\ Janaina Coser $^{1}$, Janice de Fatima Pavan Zanella ${ }^{1}$, Diego Pascoal Golle ${ }^{2}$, Gabriela Tassotti Gelatti ${ }^{1}$ \\ \& Rodrigo Fernando dos Santos Salazar ${ }^{1}$
}

\begin{abstract}
${ }^{1}$ Laboratório de Estresse Oxidativo, Programa de Pós-Graduação em Atenção Integral a Saúde, Universidade de Cruz Alta (UNICRUZ), Campus Universitário Dr. Ulisses Guimarães, Parada Benito, Cruz Alta, RS, Brazil

${ }^{2}$ Laboratório de Cultura in vitro, Mestrado Profissional em Desenvolvimento Rural, Universidade de Cruz Alta (UNICRUZ), Campus Universitário Dr. Ulisses Guimarães, Parada Benito, Cruz Alta, RS, Brazil

Correspondence: Roberta Cattaneo Horn, Laboratório de Estresse Oxidativo, Programa de Pós-Graduação em Atenção Integral a Saúde, Universidade de Cruz Alta (UNICRUZ), Campus Universitário Dr. Ulisses Guimarães, Rod. Municipal Jacob Della Méa, km 5.6, Parada Benito, 98020-290, Cruz Alta, RS, Brazil. E-mail: rcattaneo@unicruz.edu.br
\end{abstract}

Received: April 12, $2017 \quad$ Accepted: May 11, $2017 \quad$ Online Published: June 15, 2017

doi:10.5539/jas.v9n7p97 URL: https://doi.org/10.5539/jas.v9n7p97

\begin{abstract}
The aim of the present study is to investigate in vitro antioxidant activity of Cunila microcephala Benth infusion (Poejo) in erythrocytes from individuals with HIV/AIDS. Erythrocytes were used from seventeen patients of both sexes, with HIV/AIDS, receiving antiretroviral therapy and the control group consisted of erythrocytes of HIV/AIDS free individuals belonging to both sexes. The erythrocytes were treated in vitro for an hour with infusions of Poejo at the following concentrations: 1, 5, 10, 25 and $50 \mathrm{~g} / \mathrm{L}$ After treatment, the levels of thiobarbituric acid reactive substances (TBARS), carbonylated proteins (CPs), and reduced glutathione (GSH) were measured. A reduction in lipoperoxidation and protein carbonylation was observed after treatment with poejo tea at the concentrations of $5,10,25$ and $50 \mathrm{~g} / \mathrm{L}$. In addition, a reduction of $\mathrm{GSH}$ at such concentrations was observed. Poejo infusion appears to perform an antioxidant activity in lipid oxidation and in the protein carbonylation found in individuals with HIV/AIDS.
\end{abstract}

Keywords: human immunodeficiency virus, oxidative stress, plants

\section{Introduction}

The human immunodeficiency virus (HIV) causes a chronic and progressive immune dysfunction in the body known as Acquired Immunodeficiency Syndrome (AIDS). This virus has infected more than 60 million people and caused approximately 30 million deaths worldwide due to the cytolytic infection of the CD4-like T lymphocytes (Cooper et al., 2013). Brazil has recorded 41,100 annual AIDS cases, on average, in the last five years, according to a recent report in the AIDS and STD Epidemiological Bulletin of the Ministry of Health (Brasil, 2016). Szwarcwald et al. (2008) and Martins et al. (2014) highlighted approximately 2\% increase in the AIDS detection rate, mainly in Northeastern Brazil where it increased by $62.6 \%$; however, the mortality rate increased by $33.3 \%$ in the same region, at the same period.

Although the HIV/AIDS infection outbreak emerged in the 1980s as a public health and social well-being issue and reached concerning proportions at that time, it remains worrisome (Carvalho et al., 2007). Despite the advances in HIV/AIDS diagnosis and treatment, reality presents itself as a challenge to health professionals due to the high incidence of the disease and to the impacts of it on carriers' lives (Springer et al., 2012).

Accordingly, reactive oxygen species (ROS) play an important role in T-cell proliferation and in immune defense under normal conditions. However, the excessive ROS production in HIV patients may boost the disease's progression, since it has the potential to cause significant damage to deoxyribonucleic acid (DNA), proteins and lipids by impairing the immune system's response to HIV and/or by inducing apoptosis. In addition, seropositive patients have low antioxidant compound levels, fact that neutralizes ROS and inhibits kappa nuclear 
factor (NF-kB), which is a transcription factor accelerating the viral replication process (Stephenson et al., 2006; Van Gaalen \& Wahl, 2009; Amador-Licona et al., 2016).

Multivitamin supplements and antioxidant minerals have appeared as a therapeutic adjunct used in recent decades to reduce the oxidative stress caused by HIV/AIDS. However, there is no evidence of the positive effects of the antioxidant therapy, since sometimes mortality increases due to the intake of these synthetic compounds (Bjelakovic et al., 2012, Poljsak, et al., 2013). Therefore, it is worth investigating role of possible natural compounds capable of minimizing oxidative cellular damages.

The grasshopper species Cunila microcephala Benth belongs to family Lamiaceae and is popularly known as poejinho or poejo. The species is native to Southern Brazil, Argentina and Uruguay. Its antitussive, stimulant and antispasmodic actions stand out among its main popular applications. Phytochemical studies applied to Cunila microcephala Benth have identified the presence of phenolic compounds such as tannins, coumarins and flavonoids - originating from the intermediate metabolic pathway of the shikimic acid - in the production of secondary plant metabolites. The presence of an aromatic ring and of hydroxyls is common in these compounds; this structure is responsible for the antioxidant potential of Cunila microcephala Benth (Angelo et al., 2007; Morais et al., 2009). Therefore, the aim of the present study is to investigate in vitro antioxidant activity of Cunila microcephala Benth infusion in erythrocytes from individuals with HIV/AIDS.

\section{Method}

\subsection{Ethical Aspects}

The present research was approved by the Research Ethics Committee of Cruz Alta University (UNICRUZ), protocol n. 15510413.3.0000.5322. The participants were consulted about the viability of their participation and signed the Free Consent Form.

\subsection{Preparation of Cunila microcephala Benth Infusion}

The aerial parts of the poejo of the UNICRUZ garden, Rio Grande do Sul, were used, free of flowers at the time of collection. After the collection, the aerial parts were dried in an oven at $30{ }^{\circ} \mathrm{C}$ for four days. The preparation of the infusions was obtained by pouring $150 \mathrm{ml}$ of boiling water $\left(100^{\circ} \mathrm{C}\right)$ into $10 \mathrm{~g}$ of the dry aerial parts of both plants in a glass bottle which remained closed for 10 minutes (Brasil, 2011). The other concentration stocks used in this study $(1,5,10$ and $25 \mathrm{~g} / \mathrm{L})$ were prepared from infusion of poejo at $50 \mathrm{~g} / \mathrm{L}$.

\subsection{Characterizing the Phytochemical Components}

\subsubsection{Total Polyphenols}

The sample was diluted to a concentration of $0.150 \mathrm{mg} / \mathrm{mL}$ and in this solution was added $20 \%$ sodium carbonate and Folin-Ciocalteau $2 \mathrm{~N}$ reagent. The solution was incubated for 10 minutes and the absorbance was measured, in triplicate, in spectrophotometer at $730 \mathrm{~nm}$ wavelength, according to Chandra and Mejia (2004). The total content of polyphenols was expressed through the equivalent Gallic acid $\mathrm{mg}$ per $\mathrm{ml}$ of infusion, according to the gallic acid calibration curve

\subsubsection{Flavonoids}

The total content of flavonoids was determined according to the method described by Woisky and Salatino (1998). The sample was diluted to a concentration of $1 \mathrm{mg} / \mathrm{L}$ and in this solution was added aluminum chloride and methanol. The absorbance was read at $420 \mathrm{~nm}$. The tests were done in triplicate and the quercetin standard curve was used to calculate the dose. The content of flavonoids was expressed through milligrams of quercetin per infusion $\mathrm{mL}$.

\subsubsection{Condensate Taninns}

Condensate tannins were determined through the method described by Morrison et al. (1995), with some modifications. The sample was diluted in $25 \mathrm{mg} / \mathrm{mL}$ ethanol; subsequently, vanillin ( $1 \mathrm{~g}$ vanillin diluted in 100 $\mathrm{mL}$ ethanol) and hydrochloric acid $8 \%$ in methanol solutions were added to the sample. The absorbance was set at $500 \mathrm{~nm}$. The analysis was conducted in triplicate and the total content of tannins was expressed through the equivalent milligrams of catechin per infusion $\mathrm{mL}$.

\subsection{Sample Collection and Processing}

Biological material from seventeen patients belonging to both sexes from random, with HIV/AIDS, receiving antiretroviral therapy, was collected through venipuncture by using vacuum tubes containing ethylenediaminetetraacetic acid (EDTA). The biological material was homogenized and packed in thermal boxes after collection. Subsequently, the samples were centrifuged at $3000 \mathrm{rpm}$ for 10 minutes and the plasma was 
removed. The erythrocytes were washed three times in isotonic saline solution and diluted with saline solution $0.9 \%$ until reaching $5 \%$ hematocrit (Horn et al., 2015). After dilution, the supernatant was discarded and the erythrocytes of each participant were divided in six treatment groups:

Basal group (poejo infusion free): Erythrocytes from HIV/AIDS individuals treated with saline solution;

Group 1: Erythrocytes from HIV/AIDS individuals treated with poejo infusion at $1 \mathrm{~g} / \mathrm{L}$;

Group 5: Erythrocytes from HIV/AIDS individuals treated with poejo infusion at $5 \mathrm{~g} / \mathrm{L}$;

Group 10: Erythrocytes from HIV/AIDS individuals treated with poejo infusion at $10 \mathrm{~g} / \mathrm{L}$;

Group 25: Erythrocytes from HIV/AIDS individuals treated with poejo infusion at $25 \mathrm{~g} / \mathrm{L}$;

Group 50: Erythrocytes from of HIV/AIDS individuals treated with poejo infusion at $50 \mathrm{~g} / \mathrm{L}$.

Erythrocytes from seventeen HIV/AIDS-free individuals belonging to both sexes were used to compose the control group. The erythrocytes were treated in vitro for one hour in water bath at $37{ }^{\circ} \mathrm{C}$. Subsequently, the samples were vortexed for erythrocyte hemolysis and centrifuged at $3600 \mathrm{rpm}$ for 15 minutes for supernatant removal, which allowed performing the analytical determinations.

\subsection{Analytical Determinations}

\subsubsection{Determining the Thiobarbituric Acid Reactive Substances (TBARS)}

The TBARS were measured according to the protocol described by Stocks and Dormandy (1971). The supernatant was added with the reaction mixture of trichloroacetic acid (TCA) to $28 \%(\mathrm{v} / \mathrm{v})$ thiobarbituric acid (TBA) at $0.1 \mathrm{~mol} / \mathrm{L}$, at $95{ }^{\circ} \mathrm{C}$. The readings were taken at $532 \mathrm{~nm}$. The results were expressed as $\eta \mathrm{mol} \mathrm{MDA} / \mathrm{g}$ $\mathrm{Hb}$. The hemoglobin level analysis was conducted according to the recommendations in the Labtest ${ }^{\mathbb{B}}$ commercial $^{-}$ kit.

\subsubsection{Determining the Levels of Carbonyl Proteins (CPs)}

The CPs level analyses were performed through the technique described by Levine (1990), adapted to erythrocytes, wherein the trichloroacetic acid (TCA) is used at $10 \%(\mathrm{v} / \mathrm{v}), 2 \mathrm{~N}$ hydrochloric acid; 2,4-Dinitrofenilhidrazina (DNPH) in $10 \mathrm{mM}$ and sodium dodecyl sulfate (SDS) $3 \%(\mathrm{~m} / \mathrm{v})$ in the reaction mixture. The readings were carried out in visible spectrophotometer, at $370 \mathrm{~nm}$. The results were expressed in $\eta \mathrm{mol}$ carbonyl/mg protein.

\subsubsection{Determining the Levels of Reduced Glutathione (GSH)}

The GSH levels were determined through the technique described by Ellman (1959), adapted for erythrocytes, which uses a potassium phosphate buffer (TFK) at $1 \mathrm{M}, \mathrm{pH}$ 7.4, and acid 5,5'-ditiobis-(2-nitrobenzoic) (DTBN). The procedure was performed in ice bath and the readings were realized in visible spectrophotometer, at $412 \mathrm{~nm}$. The results were expressed as $\mu \mathrm{mol} \mathrm{GSH} / \mathrm{Hb}$. The hemoglobin level analysis was conducted according to the recommendations in the Labtest ${ }^{\circledR}$ commercial kit.

\subsection{Statistical Analysis}

The phytochemical extract and the lemongrass infusion featuring was carried out in triplicate and the results were expressed through mean \pm standard deviation. The results were subjected to Student t-test for parametric data collection, by taking the significantly different rates $(\mathrm{p}<0.001)$ into consideration.

The analytical determinations of all samples were performed in triplicate and the results were expressed through \pm SEM (standard error of the mean). The distribution of variables was tested through the Kolmogorov-Smirnov test, Shapiro-Wilk normality test and D'Agostino-Person omnibus normality test Data concerning all studied groups, for the same parameters, were subjected to the one-way variance analysis (ANOVA), followed by Tukey-Kramer test. Significantly different rates, at $\mathrm{p}<0.05$, were considered.

\section{Results}

There was an increase in the levels of TBARS and CPs in HIV-positive individuals when compared to the control group (Figures 1A and 2A). After in vitro treatment with poejo infusion there was a reduction of $20.75 \%$, $67.13 \%, 46.55 \%$ and $66.57 \%$ in TBARS levels at concentrations of $5,10,25$ and $50 \mathrm{~g} / \mathrm{L}$ respectively when compared to basal (Figure 1B). Regarding CPs levels, there was a reduction of $56.33 \%, 47.37 \%, 52.71 \%$ and $34.36 \%$ in the concentrations of 5, 10, 25 and $50 \mathrm{~g} / \mathrm{L}$ respectively when compared to basal (Figure $2 \mathrm{~B}$ ).

Regarding GSH, a reduction of this antioxidant was observed in HIV-positive individuals when compared to the control group (Figure 3A). There was a reduction of this biomarker after the in vitro treatment with the infusion 
of poejo in the concentrations of $1,5,10,25$ and $50 \mathrm{~g} / \mathrm{L}$. This reduction was $97.38 \%, 78.81 \%, 88.24 \%, 61.94 \%$ and $71.82 \%$, respectively, when compared to basal (Figure 3B).

$1 \mathrm{~A}$

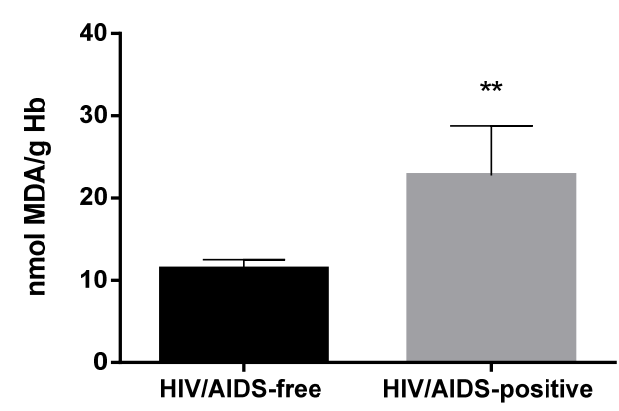

1B

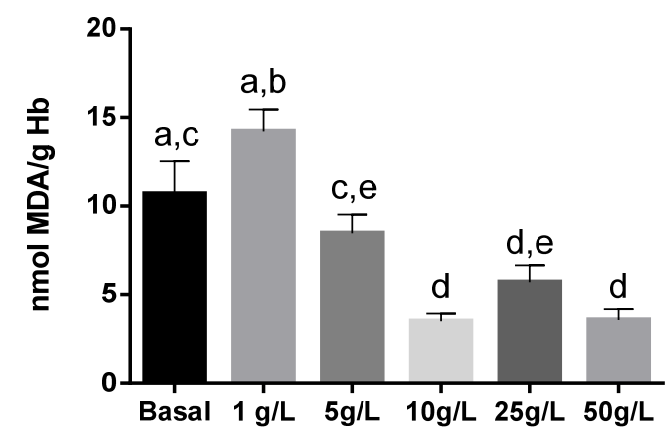

Figure 1. TBARS levels ( $\eta \mathrm{mol} \mathrm{MDA} / \mathrm{g} \mathrm{Hb}$ ) in erythrocytes from HIV/AIDS-free patients and from HIV/AIDS-positive patients (1A). TBARS levels ( $\eta$ mol of MDA/g Hb) in erythrocytes from HIV/AIDS-positive patients after the exposure to Cunila microcephala Benth infusion at concentrations 1, 5, 10, 25 and $50 \mathrm{~g} / \mathrm{L}(1 \mathrm{~B})$.

Values expressed as Mean \pm Standard error. Different letters represent significantly different statistics, at $\mathrm{p}<0.05$

2A

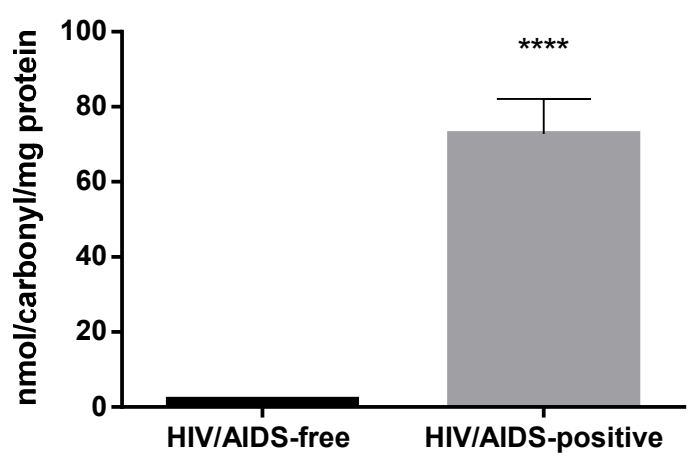

2B

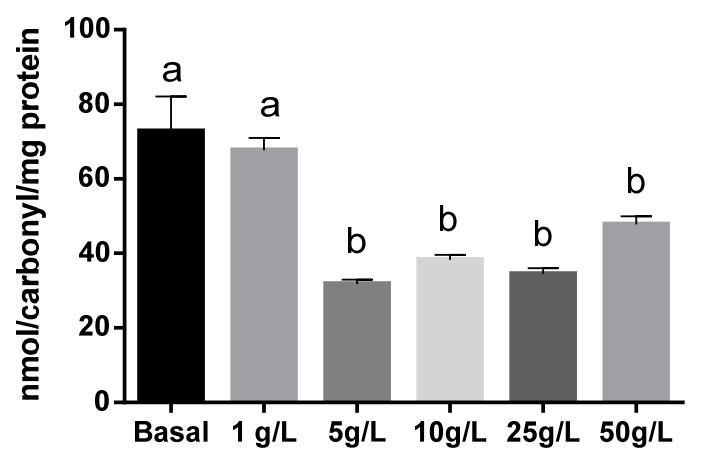

Figure 2. CPs levels ( $\eta \mathrm{mol}$ carbonyl/mg protein) in erythrocytes from HIV/AIDS-free and HIV/AIDS-positive patients (2A). CPs levels ( $\eta$ mol carbonyl/mg protein) in erythrocytes from HIV/AIDS-positive patients after the exposure to Cunila microcephala Benth infusion at concentrations 1, 5, 10, 25 and $50 \mathrm{~g} / \mathrm{L}$ (2B). Values expressed as Mean \pm Standard error. Different letters represent significantly different statistics at $p<0.05$ 
3A

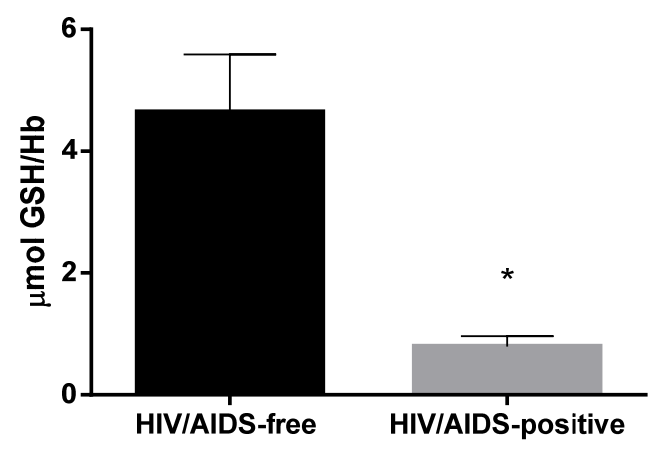

3B

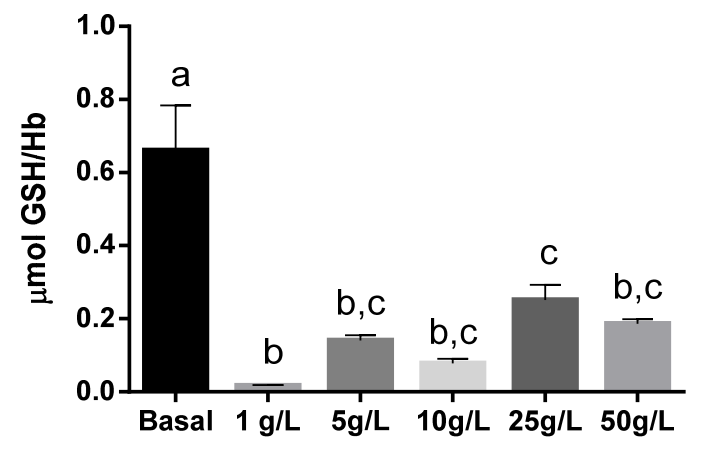

Figure 3. GSH levels ( $\mu \mathrm{mol} \mathrm{GSH} / \mathrm{Hb})$ in erythrocytes from HIV/AIDS-free and HIV/AIDS-positive patients (3A). GSH levels ( $\mu \mathrm{mol} \mathrm{GSH} / \mathrm{Hb})$ in human erythrocytes from HIV/AIDS-positive patients after the exposure to Cunila microcephala Benth infusion at concentrations 1, 5, 10, 25 and $50 \mathrm{~g} / \mathrm{L}$ (3B). Values expressed as Mean \pm Standard error. Different letters represent significantly different statistics, at $\mathrm{p}<0.05$

\section{Discussion}

Human blood is an excellent source of oxidative stress markers in vivo, since it transports and redistributes antioxidants and endobiotics modified by the action of reactive species. Erythrocytes, particularly, are anucleated cells, lacking the ability to repair damages caused by oxidation. In addition, the plasma membrane in this cell is one of the main damage targets, fact that turns it into a widely used experimental oxidative stress model (Begum \& Terao, 2002; Schmitz, 2008). Therefore, oxidative damages, as well as the possible antioxidant activity observed in the erythrocytes, slightly demonstrate individuals' cellular behaviors.

Accordingly, it is possible quantifying the lipid peroxidation levels, which are set by the attack of species reactive to the lipids found in the cell membrane. Ogunro et al. (2005) have shown that patients with type I HIV have malondialdehyde (MDA) levels - which is a byproduct of lipid peroxidation - much higher than those in the control group. It corroborates the increased levels of TBARS found in the present study (Figure 1A), in which the lipoperoxidation levels in HIV/AIDS patients are comparable to the same level of these biomarkers in healthy patients. Figure 1B, on the other hand, shows the TBARS levels after the erythrocytes' treatment with poejo infusion; thus revealing that the lipoperoxidation was lower after the treatment using poejo tea in the highest tested concentrations, 5, 10, 25 and $50 \mathrm{~g} / \mathrm{L}$.

Felisbino et al. (2014) identified the presence of antioxidant phytochemicals, such as phenolic compounds, tannins, flavonoids and coumarins - which could justify the lipid oxidation reduction (these substances are potent ER sequesters) - in Cunila microcephala Benth leaves. The features of the herein used mother infusion $(50 \mathrm{~g} / \mathrm{L})$ also corroborate the findings of the aforementioned author, by considering that polyphenols $(70.96 \pm$ $1.02 \mathrm{mg}$ gallic acid $/ \mathrm{mL}$ infusion), flavonoids $(34.50 \pm 0.14 \mathrm{mg}$ quercetin $/ \mathrm{mL}$ infusion) and tannins $(6.22 \pm 1.01$ $\mathrm{mg}$ catechin $/ \mathrm{mL}$ infusion) antioxidant effect. Overall, the antioxidant activity of phenolic compounds concerns their oxidation properties, which allow them to act as reducing agents, hydrogen donors and singlet oxygen scavengers (Guerra, 2001). According to Anila and Vijayalakshmi (2003), flavonoids and tannins are active in inhibiting membrane phospholipid peroxidation, microsomal and mitochondrial lipid peroxidation and erythrocyte peroxidation.

Figure 2A shows that the $\mathrm{CP}$ and TBARS levels in erythrocytes from HIV/AIDS-free individuals are significantly lower than the protein damage observed in HIV/AIDS carriers. Such finding was expected since lipid hydroperoxides, formed from lipoperoxidation, can attack proteins and result in the formation of these carbonyl compounds (Griffiths et al., 2014). Figure 2B, on the other hand, shows the CP levels after the erythrocytes' treatment with poejo infusion and reveals lower rates of carbonyl compounds in the highest tested concentrations 5, 10, 25 and $50 \mathrm{~g} / \mathrm{L}$. According to Höhn, König, and Grune (2013), carbonyl compound formations are irreversible; however, there are proteolytic systems removing damaged proteins and recycling amino acids for protein synthesis purposes. Therefore, it is possible suggesting that the herein tested poejo infusions may have stimulated the functioning of these proteolytic mechanisms. 
The proteolytic mechanisms mentioned above provide a last protection line against cellular oxidation and complete the performance of the endogenous antioxidant system (Höhn et al., 2013), in which GSH plays a key role. This intracellular thiol acts as cofactor for the glutathione peroxidase enzymes family, which is essential to the protection against oxidative stress.

A few years ago, Staal, Roederer, and Herzenberg (1990) reported decreased erythrocyte and plasma GSH levels in HIV-1 carriers and correlated them to AIDS progression and to the treatment with oxidant drugs. These findings were partially confirmed in the present study, if one considers that the GSH levels from HIV/AIDS patients were significantly lower than in the studied HIV/AIDS-free individuals (Figure 3A). It is worth noticing that the erythrocytes GSH levels maintain the cysteine residues of hemoglobin and other proteins. Thus, when this function fails, meta-hemoglobin are formed and, consequently, there is oxygen carrying capacity loss. Such loss leads to tissue hypoxia (Sies, 1999) and can induce the generation of more reactive species, since the non-transported oxygen tends to lose two electrons from its last layer and produce superoxide radicals or also by additional enzymatic and metabolic actions, can form other types of unpaired oxygen molecules, which are generically known as ROS (Dröge, 2002; Gottlieb et al., 2011).

After the erythrocytes from HIV/AIDS carriers were treated with poejo infusions, the GSH levels showed further reduction at all tested concentrations. Accordingly, the reduced GSH levels can be explained by the decreased TBARS and PCs levels, since the enzymatic antioxidants are responsible for the decreased GSH-dependent lipid and protein damages.

\section{Conclusion}

Poejo infusion appears to perform an antioxidant activity in lipid oxidation and in the protein carbonylation found in individuals with HIV/AIDS. Therefore, in the future, this plant may become a natural therapeutic adjuvant used to reduce oxidative stress in seropositive patients.

\section{References}

Agência Nacional de Vigilância Sanitária. (2011). Formulário de Fitoterápicos da Farmacopeia Brasileira (p. 126). Brasília, Brasil.

Amador-Licona, N., Díaz-Murillo, T. A., Gabriel-Ortiz, G., Pacheco-Moises, F. P., Pereyra-Nobara, T. A., et al. (2016). Omega 3 fatty acids supplementation and oxidative stress in HIV-seropositive patients: A clinical trial. PloS One, 11(3), e0151637. https://doi.org/10.1371/journal.pone.0151637

Angelo, P. M., \& Jorge, N. (2007). Compostos Fenólicos em alimentos-Uma breve revisão. Revista Instituto Adolfo Lutz, 66(1), 1-9.

Anila, L., \& Vijayalakshmi, N. R. (2003). Antioxidant action of flavonoids from Mangifera indica and Emblica officinalis in hypercholesterolemic rats. Food Chemistry, 83(4), 569-574. https://doi.org/10.1016/S03088146(03)00155-9

Begum, A. N., \& Terao, J. (2002). Protective effects of alpha-tocotrienol against free radical induced impairment of erythrocyte deformability. Bioscience, Biotechnology, and Biochemistry, 66(2), 398-403. https://doi.org/ $10.1271 / \mathrm{bbb} .66 .398$

Bjelakovic, G., Nikolova, D., Gluud, L. L., Simonetti, R. G., \& Gluud, C. (2012). Antioxidant supplements for prevention of mortality in healthy participants and patients with various diseases. Cochrane Database of Systematic Reviews, 14(3), CD007176. https://doi.org/10.1002/14651858.CD007176.pub2

Carvalho, F. T., Morais, N. A., Koller, S. H., \& Piccinini, C. A. (2007). Fatores de proteção relacionados à promoção de resiliência em pessoas que vivem com HIV/AIDS. Caderno de Saúde Pública, 23(9), 2023-2033. https://doi.org/10.1590/S0102-311X2007000900011

Chandra, S., \& Meija, E. G. (2004). Polyphenolic compounds, antioxidantcapacity and quinone reductase activity of an aqueous extract of Ardisia compressa in comparision to mate (Ilex paraguariensis) and Green teas (Camellia sinensis). Journal of Agricultural and Food Chemistry, 52(11), 3583-3589. https://doi.org/10.1021/jf0352632

Cooper, A., García, M., Petrovas, C., Yamamoto, T., Koup, R. A., \& Nabel, G. J. (2013). HIV-1 causes CD4 cell death through DNA-dependent protein kinase during viral integration. Nature, 498(7454), 376-379. https://doi.org/10.1038/nature12274

Dröge, W. (2002). Free radicals in the physiological control of cell function. Physiological Reviews, 82(1), 47-95. https://doi.org/10.1152/physrev.00018.2001 
Ellman, G. L. (1959). Tissue sulfhydryl group. Archives of Biochemistry and Biophysics, 7(1), 70-82. https://doi.org/10.1016/0003-9861(59)90090-6

Felisbino, A. S., Borges, M. S., Leffa, D. D., da Silva Cardoso, P., Pich, C. T., de Andrade, V. M., \& Amaral, P. A. (2014). Preliminary investigation on phytochemical composition and biological activity of Cunila microcephala Benth. Journal of Medicinal Plants Research, 8(21), 780-787. https://doi.org/10.5897/ JMPR2014.5428

Gottlieb, M. G. V., Morassutti, A. L., \& Cruz, I. B. M. (2011). Transição epidemiológica, estresse oxidativo e doenças crônicas não transmissíveis sob uma perspectiva evolutiva. Scientia Medica, 21(2), 69-80.

Griffiths, H. R., Dias, I. H., Willetts, R. S., \& Devitt, A. (2014). Redox regulation of protein damage in plasma. Redox Biology, 2, 430-435. https://doi.org/10.1016/j.redox.2014.01.010

Guerra, J. I. (2001). Oxidative stress, diseases and antioxidant treatment. Anales de Medicina Interna, 18(6), 326-335.

Höhn, A., König, J., \& Grune, T. (2013). Protein oxidation in aging and the removal of oxidized proteins. Journal of Proteomics, 92, 132-159. https://doi.org/10.1016/j.jprot.2013.01.004

Horn, R. C., Soares, J. C., Mori, N. C., Gelatti, G. T., Manfio, C. E., Golle, D. P., Koefender, J., Deuschle, R. A., \& Oliveira, C. (2015). Antioxidant effect of Physalis Peruviana fruit aqueous extract. Journal of Agricultural Science, 7(12), 137-143. https://doi.org/10.5539/jas.v7n12p137

Levine, R. L. (1990). Determination of carbonil in oxidatively modified proteins. Methods in Enzymology, 186, 464-468. https://doi.org/10.1016/0076-6879(90)86141-H

Martins, T., Kerr, L. R. F. S., Kendall, C., \& Mota, R. M. S. (2014). Cenário Epidemiológico da Infecção pelo HIV e AIDS no Mundo. Fisioterapia \& Saúde Funcional, 3(1), 4-7.

Ministério da Saúde. Secretaria de Vigilância em Saúde. (2016). Boletim Epidemiológico - HIV e AIDS (Ano V, Número 1, p. 64). Brasil.

Morais, S. M., Cavalcanti, E. S., Costa, S. M., \& Aguiar, L. A. (2009). Ação antioxidante de chás e condimentos de grande consumo no Brasil. Revista Brasileira de Farmacognosia, 19(1), 315-320. https://doi.org/ 10.1590/S0102-695X2009000200023

Morrison, M., Asiedu, E. A., Stuchbury, T., \& Powell, A. A. (1995). Determination of lignin and tannin contents of cowpea seeds coats. Annals of Botany, 76(3), 287-290. https://doi.org/10.1006/anbo.1995.1097

Ogunro, P. S., Ogungbamigbe, T. O., Ajala, M. O., \& Egbewale, B. E. (2005). Total antioxidant status and lipid peroxidation in HIV-1 infected patients in a rural area of south western Nigeria. African Journal of Medicine and Medical Sciences, 34(3), 221-225.

Poljsak, B., Suput, D., \& Milisav, I. (2013). Achieving the balance between ROS and antioxidants: When to use the synthetic antioxidants. Oxidative Medicine and Cellular Longevity, 2013. https://doi.org/10.1155/ 2013/956792

Schmitz, W. O., Simão, A. N. C., Cecchini, R., \& Saridakis, H. O. (2008). Estresse oxidativo em eritrócitos: Efeito antioxidante e antihemolítico do chá verde (Camellia sinensis). Arquivos de Ciências da Saúde da UNIPAR, 12(3), 175-179.

Sies, H. (1999). Glutathione and its role in cellular functions. Free Radical Biology and Medicine, 27(9), 916-921. https://doi.org/10.1016/S0891-5849(99)00177-X

Springer, S., Dushai, A., \& Azar, M. (2012). The impact of DSM-IV mental disorders on adherence to combination antiretroviral therapy among adult persons living with HIV/AIDS: A systematic review. Aids Behavior, 16(8), 2119-2143. https://doi.org/10.1007/s10461-012-0212-3

Staal, F. J., Roederer, M., \& Herzenberg, L. A. (1990). Intracellular thiols regulate activation of nuclear factor kappa B and transcription of human immunodeficiency virus. Proceedings of the National Academy of Sciences, 87(24), 9943-9947. https://doi.org/10.1073/pnas.87.24.9943

Stephenson, C. B., Marquis, G. S., Jacob, R. A., Kruzich, L. A., Douglas, S. D., \& Wilson, C. M. (2006). Vitamins $\mathrm{C}$ and $\mathrm{E}$ in adolescents and young adults with HIV infection. The American Journal of Clinical Nutrition, 83(4), 870-879.

Stock, J., \& Dormandy, T. L. (1971). The autoxidation of human red cell lipids induced by hydrogen peroxide. British Journal of Haematology, 20(1), 95-111. https://doi.org/10.1111/j.1365-2141.1971.tb00790.x 
Szwarcwald, C. L., Barbosa Júnior, A., Souza-Júnior, P. R. B. D., Lemos, K. R. V. D., Frias, P. G. D., Luhm, K. R., ... Esteves, M. A. P. (2008). HIV testing during pregnancy: use of secondary data to estimate 2006 test coverage and prevalence in Brazil. The Brazilian Journal of Infectious Diseases, 12(3), 167-172. https://doi.org/10.1590/S1413-86702008000300002

Van Gaalen, R. D., \& Wahl, L. M. (2009). Reconciling conflicting clinical studies of antioxidant supplementation as HIV therapy: A mathematical approach. BMC Public Health, 9(1), 1-18 https://doi.org/10.1186/1471-2458-9-S1-S12

Woisky, R. G., \& Salatino, A. (1998). Analysis of própolis: Some parameters and procedures for chemical quality control. Journal of Apicultural Research, 37, 99-105. https://doi.org/10.1080/00218839.1998. 11100961

\section{Copyrights}

Copyright for this article is retained by the author(s), with first publication rights granted to the journal.

This is an open-access article distributed under the terms and conditions of the Creative Commons Attribution license (http://creativecommons.org/licenses/by/4.0/). 